\section{Eclipse of power}

\section{Jay M. Pasachoff and Naomi Pasachoff appraise Alexander Borodin's solar-inspired opera.}

A mong the astronomical phenomena that spur composers to creativity, total solar eclipses figure rarely. A great exception is the one that inspired the nineteenth-century opera Prince Igor by Alexander Borodin. Borodin, a composer, surgeon and research chemist, based the work on a twelfth-century epic poem about Russia's foundation, The Lay of the Host of Igor, which features a momentous eclipse. Now, for the first time in nearly a century, Prince Igor is being performed at New York's Metropolitan Opera, with star bass Ildar Abdrazakov in the title role.

The opera had a convoluted genesis. After working on it intermittently for 18 years, Borodin died in 1887 , leaving it unfinished; Russian composers Nikolai Rimsky-Korsakov and Alexander Glazunov then provided most of the orchestrations. The Met's new production, a joint venture with Amsterdam's De Nederlandse Opera, reconceives the work, making use of decades of musicological research. Director Dmitri Tcherniakov and conductor Gianandrea Noseda have jettisoned much of the RimskyKorsakov and Glazunov material, incorporated newly found pieces by Borodin himself, and rearranged some scenes after referring to Borodin's notes.

This fresh version - sung in Russian for the first time here - certainly makes for an effective spectacle. Projected video footage in black and white with vivid touches of colour (such as red on a bloodied face) fleshes out aspects of the story. For instance, in the first act, conceived as a dream sequence of Igor's as he lies wounded in the field, the battle scenes are shown in this way. These are lent a certain poignancy by the fact that Borodin had worked as a military surgeon for a year. (He was, however, primarily a chemist. Best known for his research on aldehydes, he was also one of two independent discoverers of the aldol reaction, a means of forming carbon-carbon bonds in organic chemistry.)

The opera's plot hinges on the defeat, psychological journey and redemption of Prince Igor Svyatoslavich. A historical ruler of Putivl in modern-day Ukraine, he is at war against the Polovtsy nomads, who have laid waste to Russia. The eclipse appears just five minutes into the prologue, a portent of Igor's military failure. The light coming through the windows darkens for a few seconds. "The sky grows

\section{$\checkmark$ NATURE.COM}

For more on science and opera:

go.nature.com/dqsxzs dark? What does it mean? It is a sign from heaven," sings the chorus, begging the soldiers not to go to war. "The Sun is a crescent, like the Moon." The solar motif runs through the opera: in the third act, Igor, devastated by his defeat, evokes the Sun again: "I will save my people ... the Sun will shine again." Ultimately, Borodin throws off the pall of superstition to show that humans - not celestial events - are in charge. At the very end, the prince, with an abruptness that we found unconvincing, begins to salvage wood from the ruins to rebuild his city, once again leading his people.

Some six years before this magnificently staged and sung psychological drama reached the Met stage, we were on our way to Siberia to reconnoitre ahead of a total solar eclipse. Stopping off in St Petersburg, we encountered the eclipse-centred story of Prince Igor for the first time. A stunning 1942 painting by Russian artist Nicholas Roerich in the State Russian Museum shows Igor and his soldiers viewing the corona-rimmed lunar silhouette in the sky. Intrigued, we later consulted maps to find that there were indeed total solar eclipses visible from the Russian steppes in the twelfth century. Totality from the 1 May 1185 eclipse ended in what is now Ukraine - the very territory in which Prince Igor was jolted by daytime darkness.

Jay M. Pasachoff is Field Memorial Professor of Astronomy at Williams College, Williamstown, Massachusetts, and Chair of the American Astronomical Society's Historical Astronomy Division. Naomi Pasachoff, a research associate at Williams College, is a biographer of Marie Curie and other scientists.

e-mail:eclipse@williams.edu

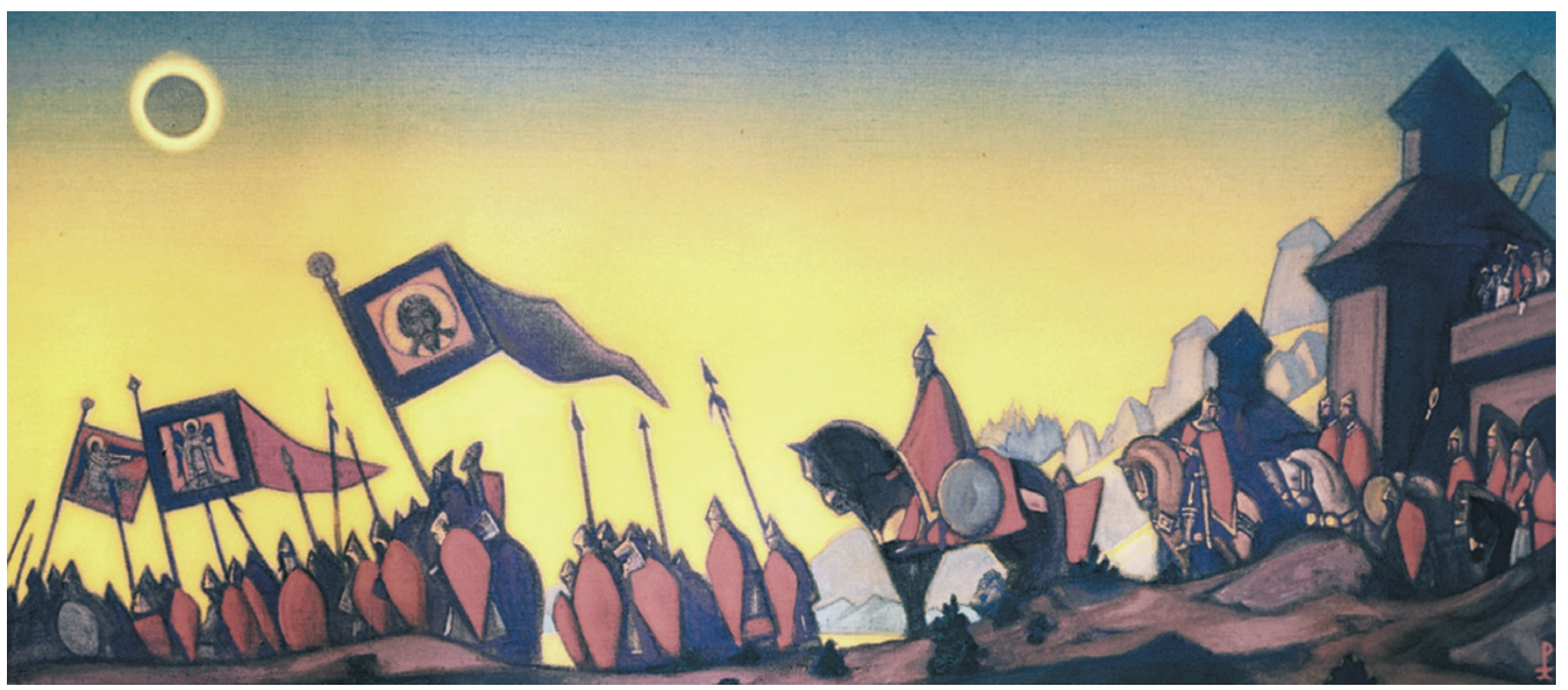

Nicholas Roerich's 1942 painting Igor's Campaign depicts the eclipse at the heart of Prince Igor. 